\title{
Innovation Capability and Performance of Manufacturing SMEs: The Paradoxical Effect of IT Integration
}

\author{
Louis Raymond* \\ Université du Québec à Trois-Rivières \\ 3351, boul. des Forges C.P. 500 \\ Trois-Rivières QC \\ Canada G9A 5H7 \\ phone : 819-376-5011 ext. 3160 \\ email : louis.raymond@uqtr.ca \\ François Bergeron \\ TELUQ-Université du Québec \\ email : bergeron.francois@teluq.ca \\ Anne-Marie Croteau \\ Concordia University \\ email: anne-marie.croteau@concordia.ca
}

*author for correspondence

Short form title - Innovativeness of SMEs: Effect of IT Integration

\begin{abstract}
In theory, IT integration through applications such as ERP, MRP-II and EDI provides an organization with the ability to exploit innovation capabilities. Based on survey data obtained from 309 Canadian manufacturing SMEs, this study aims to identify the enabling effect of IT integration upon the innovation capability of manufacturing SMEs, that is, in terms of growth and productivity outcomes, and to verify if this effect is subject to industry influences. While the firm's innovation capability was found as expected to be positively related to the growth and productivity of manufacturing SMEs, the results underline paradoxical effects of IT integration in this regard. While IT integration was seen to enable the innovation capability of manufacturing SMEs in terms of growth, it was also seen to have a disabling effect on this same capability with regard to productivity.
\end{abstract}

Keywords: innovation capability, product innovation, process innovation, IT integration, R\&D, growth, productivity, innovation, SME, paradox 


\title{
Innovation Capability and Performance of Manufacturing SMEs: The Paradoxical Effect of IT Integration
}

\begin{abstract}
In theory, IT integration through applications such as ERP, MRP-II and EDI provides an organization with the ability to exploit innovation capabilities. Based on survey data obtained from 309 Canadian manufacturing SMEs, this study aims to identify the enabling effect of IT integration upon the innovation capability of manufacturing SMEs, that is, in terms of growth and productivity outcomes, and to verify if this effect is subject to industry influences. While the firm's innovation capability was found as expected to be positively related to the growth and productivity of manufacturing SMEs, the results underline paradoxical effects of IT integration in this regard. While IT integration was seen to enable the innovation capability of manufacturing SMEs in terms of growth, it was also seen to have a disabling effect on this same capability with regard to productivity.
\end{abstract}

Keywords: innovation capability, product innovation, process innovation, IT integration, R\&D, growth, productivity, innovation, SME, paradox

\section{Introduction}

Innovation has long been considered as the key factor for the survival, growth and development of small and medium-sized enterprises (SMEs) (Acs and Audretsch, 1990; Becheikh, Landry and Amara, 2006). Developing their capacity to innovate is a mission-critical task for all organizations. Given the specificities of SMEs with regard to their environment, strategy, structure and technology, more research in this specific context is thus needed, including information technology (IT) in particular (Gable and Stewart, 1999; Premkumar, 2003). These specificities also imply that research findings in the large enterprise context do not automatically extend to small companies (Thong, Yap and Raman, 1996; Pflughoeft et al., 2003). As SMEs differ from large organizations, a greater innovation capacity is deemed to counterbalance their greater vulnerability in a global business environment and in an economy that is now knowledge-based (Hoffman, Parejo, Bessant and Perren, 1998; Roper and Love, 2002). 
Innovation is defined as "the economic application of a new idea" (Subrahamaya, 2005, p. 270). The ability to innovate is considered to be one of the most if not the most important strategic capability of manufacturing SMEs (Branzei and Vertinsky, 2006). This capability encompasses two components, namely product and process innovation capabilities, where product innovation refers to a new or modified version of a product; and process innovation looks into a new or modified way of making a product (Subrahamaya, 2005).

In response to increased competitive pressures brought about by globalization, the manufacturing strategy of SMEs in the last decade has been implemented in part through the adoption and integration of information technology (IT) in the form of planning and logistics applications such as EDI and ERP (Muscatello, Small and Chen, 2003), primarily designed to integrate cross-functional and inter-organizational business processes (Banker, Bardhan, Chang and Lin, 2003; Barki and Pinsonneault, 2005; Park and Kusiak, 2005). In IS research, the dominant paradigm is that implementing IT-based applications such as EDI and ERP is "assumed to be beneficial" (Fichman, 2004, p. 314). Thus, implementing IT is aimed at providing an organization with the "ability to accomplish speed, accuracy, and cost economy in the exploitation of innovation opportunities" (Sambamurthy, Bharadwaj and Grover, 2003, p. 246). Business agility, speed to market, productivity, cost reduction and process re-engineering are among the top five management concerns of IT executives in 2011 (Luftman and Ben-Vzi, 2011). But while information technologies are deemed to enable manufacturing SMEs to grow and be more productive by creating business value in synergy with other organizational factors (Kohli and Grover, 2008), their specific role with regard to product and process innovation capabilities needs to be further understood (Tarafdar and Gordon, 2007).

It is still unclear how and under what conditions IT integration contributes to firm performance. For example, Aral, Brynjolfsson and Wu (2008) observed that purchase events of ERP are uncorrelated with performance while go-live events are positively correlated with performance. To add to the complexity of the situation, they explain that a causal relationship between ERP and performance triggers additional IT adoption in firms that derive value from their initial investment. These authors conclude on the existence of a virtuous cycle in the investment in - and use of enterprise systems; that is the more systems are used by employees; more inclined organizations are to 
invest in such applications, which again will incite users to adopt them. From another point of view, the Gartner Group has found through numerous surveys in the past five years that CEOs claim IT is a constraint to change, ranking only behind corporate culture in its importance (Furber, 2009). Finally, a study by Accenture on IT investing (2006) reports that surveyed CIOs confirm that the universal goal of using IT to achieve more with less remains elusive, as survey respondents cited an inability to close the gap between goals and results, despite average IT spending increases. This illustrates the permanent problem of managing IT for performance, managing IT integration to increase firm performance, and the sometimes detrimental effect of integrated IT solutions on performance objectives (Mankin, 2006). And for SMEs in particular, this problem is exacerbated by IT resources and IT capabilities that may be lacking with regard to innovation, flexibility and integration (Raymond and Croteau, 2009).

Based on survey data obtained from 309 Canadian manufacturing SMEs, the present study aims at a deeper understanding of the role played by IT integration with regard to product and process innovation capability. The first objective of this research is to identify the enabling effect of IT integration upon the innovation capability of manufacturing SMEs, that is, in terms of growth and productivity outcomes. The second objective is to verify if this effect is subject to industry influences, given that higher-tech industries may lack the needed IT flexibility and agility that characterize lowertech industries that make lesser use of IT solutions. Therefore, the research question is formulated as follows: To what extent does IT integration enable the innovation capability of manufacturing SMEs?

\section{Innovation Capability of Manufacturing SMEs}

In a business environment that is becoming more and more complex, manufacturing SMEs may act strategically in two basic ways. Growth-oriented firms increase their competitiveness by seeking new markets and putting the emphasis on technological leadership and product innovation (Özsomer, Calantone and Di Benedetto, 1997). Other manufacturing SMEs, more defensive in their outlook, focus on productivity in terms of reduced costs and improved delivery capabilities, by increasing the flexibility of their productive apparatus and emphasizing process innovation (De Sarbo, Di Benedetto, 
Song and Sinha, 2005; Sum, Kow and Chen, 2004; Wang, Ju, Jiang and Klein, 2008).

A basic characterization of innovation in empirical research lies in the distinction between product innovation and process innovation. Product innovation has been defined as the introduction on the market of "a product whose technological characteristics or intended uses differ significantly from those of previously produced products" or "an existing product whose performance has been significantly enhanced or upgraded", whereas process innovation is defined as "the adoption of technologically new or significantly improved production methods" (OECD, 2005, p.32). Hence, developing a product innovation capability would enable manufacturing SMEs to maintain their position in the market or their relation with important customers (Wright, Palmer and Perkins, 2005), whereas developing a process innovation capability would aim to improve their competitiveness by reducing production costs and increasing the flexibility of their productive apparatus (Lefebvre, Lefebvre and Colin, 1991).

Process management activities are reported to best support exploitative innovations when there is already some existing knowledge (Benner and Tushman, 2002), and to be advantageous for organizations that evolve in a stable environment (Benner and Tushman, 2003). One may note that there are other ways to conceptualize the effect of process and product innovation on performance, including Tidd's (2001) conceptual framework that includes environmental contingencies (uncertainty and complexity) and the degree of innovation (incremental or radical), as additional factors influencing organizational performance. Also, best product development practices such as concurrent engineering are founded on the coordination and integration of both product innovation and process innovation (Lim, Garnsey and Gregory, 2006).

The research model developed and tested in this study is based upon the conceptual distinction between product and process innovation capabilities, presuming that SMEs who emphasize either one type of activity or the other will not incur the same results with regard to the two main dimensions of their competitive performance, that is, growth and productivity (Dugal and Roy, 1996; Nyström, 2005). And these results are to be examined from a strategic perspective or competitive standpoint. For instance, following Miles and Snow's (1978) strategic typology most often used in strategic management research and also used in strategic IT research (e.g., Raymond and Croteau, 
2009), manufacturing SMEs of the "prospector" type would be more apt to emphasize their product R\&D capability in order to increase their level of product innovation and tackle new markets (Aragón-Sánchez and Sánchez-Marín, 2005). Whereas "defender" type firms would emphasise their process $R \& D$ capability in order to increase their level of process innovation, thus reducing their manufacturing costs, improving the quality of their products and services, and by the same token preserving their existing markets (O'Regan and Ghobadian, 2005). Sharing certain traits with defenders and prospectors, "analyzer" SMEs would necessitate a certain level of both product and process innovation (Slater and Narver, 1993).

In empirical studies of innovation in SMEs, researchers have sought to explain why certain firms are able to innovate more successfully than others by identifying certain strategic capabilities as vectors of innovation (Bhattacharya and Bloch, 2004), including technological integration capabilities in particular (Swink and Nair, 2007). A review of empirical studies in the manufacturing sector reveals that $37 \%$ of SMEs aimed at product innovation, $43 \%$ aimed at both product and process innovation, and only $1 \%$ at process innovation exclusively (Becheikh, Landry and Amara, 2006). In addition, accumulating evidence suggests that for SMEs, the strategic use of IT is essential in enabling innovation to be converted into increased organizational performance (Dibrell, Davis and Craig, 2008).

With regard to process innovation capability, a number of manufacturing SMEs have been found to adopt and assimilate advanced manufacturing technologies (AMT) such as computer-aided design and manufacturing (CAD/CAM) and flexible manufacturing systems (FMS) that enable them to achieve a competitive advantage with more flexibility, reduced delay (from product design to introduction on the market) and quick response to market changes (Ariss, Raghunathan and Kunnathar, 2000). Furthermore, a study of 248 manufacturing SMEs found that in terms of strategic orientation, "world-class" firms put more effort in integrating their processes whereas "local" firms focused more on developing their products, thus affecting their use and integration of AMT for strategic purposes (Raymond and Croteau, 2006). 


\section{IT Integration}

As defined by Zhu and Kraemer (2005), technology integration indicates the degree of interconnectivity between the information systems and databases of a firm and those integrated with the firm's business partners. IT integration implies a tradeoff between legacy systems and new applications, where some applications are abandoned, modified or merged. Such changes also imply modifications in the organization's structure, in its application development requirements, and in its infrastructure settings (Lin, Lo and Yan, 2010).

IT integration can take several forms: unified, federal, and fully integrated (Izza, 2009) and involve various levels of integration: physical system integration, IT application integration, and enterprise level integration (Vernadat, 2002). Summing up the literature, Izza (op. cit.) concludes that IT integration can be viewed through four dimensions: the integration scope (intra-enterprise and extra-enterprise), point of view (programmer, designer, and user), layer (data, message, and process) and level (hardware, platform, syntactic, and semantic). This illustrates the complexity of the IT integration concept and the challenges facing the organizations aiming at an IT integrated business environment.

The main benefit of IT integration lies in the reduction of prior incompatibilities between legacy systems and new applications and in the increased responsiveness of information systems (Goodhue, Wybo and Kirsh, 1992), that is, by creating operational efficiencies and organizational synergies through the sharing of resources and capabilities across functional units (Bharadwaj, 2000). However, integration may also have a "downside" (Singletary, 2004) or be detrimental in that "monolithic IT architectures may hinder agility by limiting the range of responses available to a firm" (Overby, Bharadwaj and Sambamurthy, 2006, p. 127).

Previous results indicate that IT integration allows a firm to improve its performance by reducing its cycle time, improving its customer service, and lowering its procurement costs (Barua, Konana, Whinston and Yin, 2004). An extensive research surveying 1857 organizations from 10 countries indicates that the integration of IT was the strongest factor facilitating assimilation of ebusiness innovations in developed countries. More specifically, the key factor of this assimilation was 
the shift from accumulation of various technologies to their integration (Zhu, Kraemer and $\mathrm{Xu}, 2006)$. A similar study was conducted amongst 1757 manufacturers to assess the effect of IT integration and lean/just-in-time practices on lead-time performance (Ward and Zhou, 2006). However, results of this study indicated that the customer lead-time was not directly reduced by within-firm IT integration or between-firm IT integration.

Returning to Zhu and Kreamer's (2005) definition of IT integration, the extent of such integration in the organization can be ascertained by the presence of computer-based applications that are specifically designed to enable the intra- and inter-organizational integration of information, i.e. enterprise systems that are used across the organization in all functions in order to facilitate the coordination of operations, resources and decision-making (Hwang and Grant, 2011). Indeed, the IT integration provided by these systems is deemed to be one of the main IT capabilities, along with IT flexibility and transversality that enable organizations to achieve business value from their IT investment (Uwizeyemungu and Raymond, 2012). Under this type of systems fall applications such as electronic data interchange (EDI), materials requirement planning (MRP), manufacturing resource planning (MRP-II) and enterprise resource planning (ERP) among others. Hence, the more an organization has not only adopted but rather assimilated or "mastered" the use of such applications, the greater its level of IT integration (Dechow and Mouritsen, 2005).

\section{Research Model and Hypotheses}

Because product and process innovation capabilities are interdependent yet closely linked, both product and process must be distinctively factored into innovation capability (Abernathy and Utterback, 1978; Martinez-Ros, 1999). As presented in Figure 1, the research model hypothesizes that the effect of innovation capability upon the firm's growth and productivity will be enabled by IT integration, that is, by its use of applications such as MRP-II, ERP and EDI whose ultimate aim resides in the "seamless" integration of business processes across functions and across organizations (Van Grembergen and Van Belle, 1999; Markus, 2001; Kobayashi, Tamaki and Komoda, 2003). 


\section{Figure 1: Research Model}

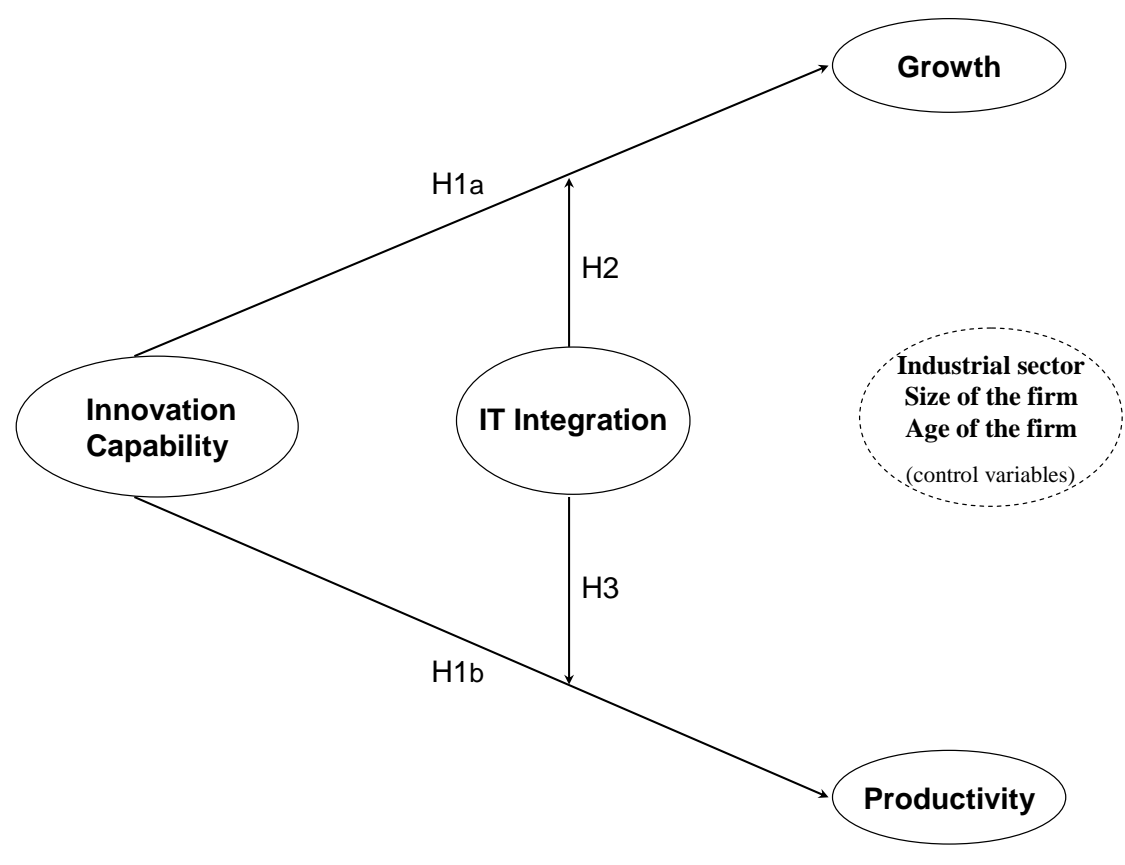

The two dependent constructs, growth and productivity, constitute the two main dimensions of the SME's competitive performance in a globalized economy (Wolff and Pett, 2006). For certain researchers, growth, that is the increased penetration of existing markets or the penetration of new markets, be they local, national or international, is intrinsically linked to entrepreneurship (Moreno and Casillas, 2007) and even constitutes its essence (Wiklund and Sheperd, 2003). For other researchers, a large number of SMEs if not the majority are not "entrepreneurial", and their ownermanagers do not show a growth orientation or intent (Nummela, Puumalainen and Saarenketo, 2005). In the manufacturing sector, the latter rather seek to maintain or increase their firm's competitiveness and financial health through productivity gains, that is, by limiting or reducing unit production costs, especially labor costs ((Rochina-Barrachina, Mañez and Sachis-Llopis, 2010).

Empirical results with regard to the relationship between growth and productivity have been mixed if not contradictory, and are subject however to numerous of contingencies related to the sector, size and age of the firm, and to other idiosyncratic factors (Bailey, Bartelsman and Haltiwanger, 1996). For instance, while some studies did not find any significant relationship between growth and productivity (Bottazzi, Secchi and Tamagni, 2008; Foster, Haltiwanger and Krizan, 2001), 
increased employment growth among SMEs was observed to accompany a decrease in productivity (Marelli and Signorelli, 2010, and greater size and age has been associated to lower productivity (Hall, Lotti and Mairesse, 2009). Hence, as the relationship between productivity and growth is not the focus of this research, there is no hypothesis in the research model linking the two dependent constructs.

Product innovation capability, be it incremental or fundamental (Fergurson and Fergurson, 1994), implies the capability of introducing a new product that maintains or increases a market share which translates into growth (Subrahmanyan, 2005). Process innovation capability is known to lead to improved productivity (Heygate, 1996; Benner and Tushman, 2002, 2003). As product and process innovation capabilities have different aims, both should positively factor into the firm's innovation capability and in turn contribute to an increase in growth and productivity. Therefore the first hypothesis is the following:

Hypothesis 1a - The firm's innovation capability has a positive impact on its growth.

Hypothesis $1 b$ - The firm's innovation capability has a positive impact on its productivity.

The role of IT integration is two-fold. It first refers to a technical aspect that includes the standardization of technology and data access (Goodhue et al., 1992; Ross, 2003). It is also related to standardization of the core business processes within a firm and/or with its business partners (Barki and Pinsonneault, 2005; Ross, 2003). However, the implementation of integrative IT does not always translate into a true integration (Bagchi and Skjoett-Larsent, 2002). Complete integration normally increases the visibility of the information but also the flexibility in accessing it (Evgeniou, 2002). This does not happen easily; in fact it often turns out to be contradictive unless the organization reaches a high level of agility (Ross, 2003; Evgeniou, 2002).

Implementing integrative IT such as ERP helps most organizations to improve the synchronization of data and systems amongst their suppliers, customers and partners. Regarding the impact of such IT investments on organizational performance, Bharadwaj, Bharadwaj and Konsynski (1995) hypothesized that the greater the IT intensiveness of a firm, the greater the (positive) impact of 
competitive structure variables such as product customization and $R \& D$ expenditure on the firm's market share performance. Integrative IT investments should be converted into an increased level of access to the information which allows the firm to adjust more rapidly and more adequately to the market and therefore increase its growth (Lee, Farhoomand and Ho, 2004). In similar fashion, a survey study of 231 service firms (Búrca, Fynes and Brannick, 2006) found IT sophistication to have a positive moderating effect on the impact of strategic practices such as benchmarking and customer relationship management upon growth. The second research hypothesis thus follows:

Hypothesis 2 - The greater the firm's IT integration, the greater the positive impact of its innovation capability on its growth.

Business process integration is a characteristic of manufacturing organizations that may bear both an opposing and a complementary relationship to manufacturing flexibility or operational agility (Srivardhana and Pawlowski, 2007). On one hand, systems such as ERP that, in theory, are meant to provide both standardization and flexibility can in fact "generate rigidities that prevent organizational innovation and adaptation" (D'Adderio, 2003, p. 335). On the other hand, integrated processes allow for greater sharing of new information, thus insuring quicker response to changes in the environment and increasing the organization's flexibility (Swafford, Ghosh and Murthy, 2008).

Hypothesis 3 - The greater the firm's IT integration, the greater the positive impact of its innovation capability on its productivity.

Note that these hypotheses imply a "fit as moderation" alignment perspective (Venkatraman, 1989), wherein fit is conceptualised as the interaction between IT integration and innovation capability. Thus, following Bharadwaj et al.'s (1995) seminal IT alignment research proposition, IT integration is hypothesized to moderate the relationship between the SME's strategic capabilities, in terms of innovation, and its organizational performance, in terms of growth and productivity.

Innovation capability is susceptible to industry effects, as observed in many studies that have demonstrated the influence of the industrial sector's technological intensity, growth, and structure (Becheikh et al., 2006; Stoel and Muhanna, 2009). For instance, product innovation capability is 
deemed to be stronger in sectors of higher technological intensity such as electronics and biotechnology (Subrahmanya, 2005). Also, prior research has confirmed the theoretical and empirical importance of industry as a contingency factor in the relationship between innovation capability and organizational performance (Kalantaridis and Pheby, 1999; Tidd, Bessant and Pavitt, 2005; RochinaBarrachina, Mañez and Sachis-Llopis, 2010). It is thus important to be able to distinguish between firm and industry effects when testing the research hypotheses (Mauri and Michaels, 1998), which is why the research model includes the technological intensity of the industrial sector as a control variable. The size and the age of the firm were also added as control variables, given their potential effect on the growth and productivity of SMEs (Delmar, Davidsson and Gartner, 2003; Freel, 2000; Kalantaridis and Pheby, 1999).

This research answers the call for more industry-focused research made by Chiasson and Davidson (2005). As per their assessment of top-tier journals in IS field, only 11 percent of surveyed articles specifically addressed any industry aspects that could explain the results. A more recent study looked into the relationship between IT capabilities and performance and discovered that industry conditions played an important role in developing and testing a theory on IT impacts (Stoel and Muhanna, 2009). By grounding our research in the SME manufacturing industry, the expected contributions should be practical and relevant to both researchers and practitioners interested in the integrative role of IT such as ERP implemented within a manufacturing SME.

\section{Research Method}

\subsection{Data collection}

The research data were obtained from a database created by a university research center, containing information on 309 Canadian manufacturing SMEs. With the collaboration of an industry association to which most of these firms belong, the database was created by having the SMEs' chief executive and functional executives such as the controller, human resources manager, and production manager fill out a questionnaire to provide data on the practices and results of their firm, including their financial statements. Anonymity and confidentiality was preserved by having the questionnaires 
transit through the industry association so that firms are known by the research center only by an alphanumeric identifier assigned by the association. After manual verification by the research center's personnel, the data were typed in via validation software and entered in the database as valid, ready for analysis.

\subsection{Measurement}

Based upon the effect of $R \& D$ investments on the subsequent growth of the firm, as confirmed in the literature (Co and Chew, 1997), these investments can be used as an indicator of the SME's capacity to innovate (Qian and Li, 2003; Wolff and Pett, 2006), and particularly in the context of SMEs (De Jong and Vermeulen, 2007). Investment in R\&D is in fact one of the most important mechanisms that constitute the innovation system in a given sector or industry (Baldwin and Hanel, 2003). The innovation capability construct is thus measured in this study by product $R \& D$ and process $R \& D$ as surrogate formative indicators. In line with common measurement practice with regard to R\&D and innovation capability (OECD, 2005), the intensity of product and process R\&D activities is measured by two ratios, namely product $R \& D$ budget over number of employees and process $R \& D$ budget over number of employees.

Following a subjective measurement approach previously used by Brandyberry, Rai and White (1999) and by Rai, Tang, Brown and Keil (2006), IT integration is measured by asking the operations manager to evaluate the extent to which the use of integrative applications such as EDI and ERP is actually mastered by the organisation, on a scale of 1 (low) to 5 (high). By summing these evaluations over six "planning and logistics" applications, using Kotha and Swamidass' (2000) categorisation of advanced manufacturing technology, one thus obtains an index (ranging from 0 to 30) of IT integration for the firm.

The most widely-used productivity indicator was selected, directly related to the firm's manufacturing systems, that is, the productivity of the workforce as measured by the gross profit per employee ratio. The indicator of growth is also one that is most commonly used, that is, the average growth in sales over the last three years. The industry variable was measured as the technological intensity of the industrial sector in which the firm operates, using the OECD's four-category 
classification commonly employed in innovation research (e.g., Barry, 2005; Santamaria, Nieto and Miles, 2011): low-tech, medium to low-tech, medium to high-tech, high-tech. The size of the firm was measured by the number of employees, while the age of the firm corresponds to the number of years since its creation.

\section{$5.3 \quad$ Sample}

For the study's purposes, a manufacturing SME is defined as an enterprise with 20 or more employees and less than 500, corresponding to the lower bound used by the European Union (Kalantaridis, 2004) and the upper bound used in North American research (Mittelstaedt, Harben and Ward, 2003). The size of the sampled firms thus varies between 20 and 405 employees, with a median of 49 , whereas annual sales vary from 0.4 to 55 million Canadian dollars, with a median of 6 . More than fifteen industrial sectors are represented, including metal products (27.5\% of the sampled firms), wood (14\%), plastics and rubber (13\%), electrical products $(6.5 \%)$, food and beverage (6\%), and machinery (5.5\%). Being relatively representative of Canadian manufacturing SMEs with regard to size and industry, 104 of the sampled firms $(34 \%)$ operate in a sector whose technological level is low, 153 (49\%) in a medium to low-tech sector, and $52(17 \%)$ in a medium to high-tech sector, there being no high-tech firms.

\section{6. $\quad$ Results}

\subsection{Descriptive Results}

As presented in Table 1, the first descriptive results pertain to the levels of IT adoption and integration in manufacturing SMEs, including manufacturing planning and logistics applications such as computer-based production scheduling, bar-coding, EDI, MRP, MRP-II and ERP that aim to and thus constitute "plant information systems" (Banker et al., 2003). Note that IT integration is ascertained here in terms of these applications rather than in terms of their underlying technologies such as Web or XML technoloy (Rai, Patnayakuni and Seth, 2006). It seems that it is still a minority of SMEs that have adopted IT for purposes of inter-process connectivity, including EDI (22\% adoption rate), MRP- 
II (10\%) and ERP (9\%). One could surmise that the sampled SMEs, in responding to the challenges of globalization, would be oriented more on manufacturing flexibility or operational agility than on integration.

Table 1: Levels of Adoption and Mastery of Integrative Applications in the SMEs

\begin{tabular}{lcc}
\hline \multicolumn{1}{c}{ Logistics/Planning applications $(\mathbf{n}=\mathbf{3 0 9})$} & Adoption rate & IT integration $^{\mathbf{a}}$ \\
\hline Computer-based production scheduling & $37 \%$ & 3.3 \\
Computer-based bar-coding & $29 \%$ & 3.7 \\
Electronic data interchange (EDI) & $22 \%$ & 3.5 \\
Materials requirement planning (MRP) & $20 \%$ & 3.1 \\
Manufacturing resource planning (MRP-II) & $10 \%$ & 2.8 \\
Enterprise resource planning (ERP) & $9 \%$ & 3.3 \\
\hline
\end{tabular}

${ }^{a}$ Mastery of the integrative application adopted (low : 1, 2, 3, 4, $5:$ high)

The descriptive statistics of the research variables are presented in Table 2, the mean being broken down by industry. SMEs in medium to high-tech sectors show the strongest product innovation capability and productivity, while their process innovation capability is equal to those in the medium to low-tech sectors. Note also that $22 \%$ of the variance in product innovation capability is explained by industry effects rather than by firm effects. There are however no significant industry effects with regard to process innovation capability, IT integration, growth and productivity.

The partial-least-squares (PLS) method was used to estimate the research model as it is appropriate when the objective is explaining variance (Gefen, Straub and Boudreau, 2000). PLS is also robust in that it does not require a large sample or normally distributed multivariate data (Fornell and Larcker, 1981), and it can detect interaction effects and handle formative constructs (Chin, Marcolin and Newsted, 2003). Given the number of parameters to be estimated in the model and the robustness of PLS, the size of the sample appears to be amply sufficient.

As the research model to be estimated is a moderation model wherein the interaction terms includes a formative construct (Innovation capability), a two-stage procedure suggested by Chin et al. (2003) and validated by Henseler and Fassott (2010) was followed. In the first stage, the formative 
indicators are used and a main effects model (without interaction terms) is estimated by PLS in order to create latent variables scores for the predictor (Innovation capability) and moderator (IT integration) constructs. In the second stage, the product of these two single construct scores is used to create the interaction term (Innovation capability $\mathrm{x}$ IT integration) used by PLS to estimate the moderation model.

Table 2: Descriptive Statistics and Breakdown of the Research Variables by Industrial sector

\begin{tabular}{|c|c|c|c|c|c|c|c|}
\hline \multirow[t]{2}{*}{ Industrial sector $^{\mathrm{a}}$} & \multicolumn{2}{|c|}{$\begin{array}{c}\text { All } \\
\text { SMEs } \\
(\mathrm{n}=309)\end{array}$} & \multirow{2}{*}{$\begin{array}{c}\text { low- } \\
\text { tech } \\
\text { SMEs } \\
(\mathrm{n}=104) \\
\text { mean }\end{array}$} & \multirow{2}{*}{$\begin{array}{c}\text { medium to } \\
\text { low-tech } \\
\text { SMEs } \\
(\mathrm{n}=153) \\
\text { mean }\end{array}$} & \multirow{2}{*}{$\begin{array}{c}\text { medium to } \\
\text { high-tech } \\
\text { SMEs } \\
(\mathrm{n}=52) \\
\text { mean }\end{array}$} & \multirow[t]{2}{*}{$\begin{array}{c}\text { Anova } \\
\text { F }\end{array}$} & \multirow{2}{*}{$\begin{array}{c}\% \text { of } \\
\text { variance } \\
\text { explained } \\
\text { by } \\
\text { Industry }\end{array}$} \\
\hline & $\begin{array}{c}\text { mean } \\
\text { min }\end{array}$ & $\begin{array}{l}\text { s.d. } \\
\text { max }\end{array}$ & & & & & \\
\hline Growth $^{\mathrm{b}}$ & $\begin{array}{r}0.17 \\
-0.29\end{array}$ & $\begin{array}{l}0.23 \\
1.85\end{array}$ & 0.17 & 0.17 & 0.18 & 0.1 & $0 \%$ \\
\hline Productivity $^{\mathrm{c}}$ & $\begin{array}{l}47022 \\
-3641\end{array}$ & $\begin{array}{r}45651 \\
390261\end{array}$ & $39173_{2}$ & $44857_{2,1}$ & $69089_{1}$ & $8.1 * * *$ & $5 \%$ \\
\hline $\begin{array}{l}\text { Product Innovation } \\
\text { Capability }^{\mathrm{d}}\end{array}$ & $\begin{array}{r}1155 \\
0\end{array}$ & $\begin{array}{r}2805 \\
26800\end{array}$ & $302_{3}$ & $768_{2}$ & $4001_{1}$ & $41.8 * * *$ & $22 \%$ \\
\hline $\begin{array}{l}\text { Process Innovation } \\
\text { Capability }^{\mathrm{e}}\end{array}$ & $\begin{array}{r}381 \\
0\end{array}$ & $\begin{array}{r}681 \\
5714\end{array}$ & $192_{2}$ & $482_{1}$ & $462_{1}$ & $6.3 * * *$ & $4 \%$ \\
\hline IT Integration ${ }^{\mathrm{f}}$ & $\begin{array}{c}7.0 \\
0\end{array}$ & $\begin{array}{r}5.7 \\
28\end{array}$ & 6.7 & 7.1 & 7.1 & 0.2 & $0 \%$ \\
\hline Size of the firm ${ }^{\mathrm{g}}$ & $\begin{array}{l}72 \\
20\end{array}$ & $\begin{array}{r}67 \\
405\end{array}$ & 61 & 81 & 68 & 2.9 & $0 \%$ \\
\hline Age of the firm $h$ & $\begin{array}{r}25 \\
2\end{array}$ & $\begin{array}{r}19 \\
122\end{array}$ & 28 & 24 & 22 & 2.0 & $1 \%$ \\
\hline
\end{tabular}

$* * *: \mathrm{p}<0.001$

${ }_{1,2,3}$ Nota. Within rows, different subscripts indicate significant $(\mathrm{p}<0.05)$ pairwise differences between means on Tamhane's $\mathrm{T} 2$ (post hoc) test.

atechnological intensity associated to the industrial sector following the OECD's (2005b) classification

- low-tech: wood, food and beverage, furniture, clothing, textile, printing, paper, leather

- low to medium-tech: metal products, metal transformation, rubber and plastics, mining products, mineral products, construction

- medium to high-tech: electrical products, machinery, chemical products, transportation equipment

baverage growth in net sales over the last 3 years

${ }^{c}$ gross profit per employee $=($ sales - cost of goods sold $) /$ no. of production employees

d product R\&D budget / no. of employees

eprocess R\&D budget / no. of employees

${ }^{\mathrm{f}} \mathrm{\Sigma}_{\mathrm{k}=1,6}\left[\right.$ mastery of integrative application $_{\mathrm{k}}$ ]

${ }^{g}$ number of employees

${ }^{h}$ number of years since creation

Table 3 provides the intercorrelations of the research constructs. One may note at the outset that the two dependent constructs, growth and productivity, are uncorrelated $(\mathrm{r}=-0.022)$, in line with previously cited research (Bottazzi, Secchi and Tamagni, 2008; Foster, Haltiwanger and Krizan, 2001). 
Table 3: Correlation Matrix of the Research Constructs

$(\mathrm{PLS}, \mathrm{n}=309)$

\begin{tabular}{lrrrrrrc}
\hline \multicolumn{1}{c}{ Construct } & \multicolumn{1}{c}{1.} & \multicolumn{1}{c}{2.} & 3. & 4. & 5. & 6. & 7. \\
\hline 1. Growth & - & & & & & & \\
2. Productivity & -0.022 & - & & & & & \\
3. Innovation capability & 0.161 & 0.229 & - & & & & \\
4. IT Integration & -0.018 & 0.066 & 0.074 & - & & & \\
5. Size of the firm & 0.075 & 0.003 & 0.037 & 0.352 & - & & \\
6. Age of the firm & -0.186 & 0.079 & -0.119 & 0.038 & 0.103 & - & \\
7. Sector $\square$ low-tech & -0.006 & -0.123 & -0.278 & -0.032 & -0.118 & 0.105 & - \\
8. $\quad \square$ medium to high-tech & 0.025 & 0.218 & 0.379 & 0.009 & -0.026 & -0.078 & -0.320 \\
\hline
\end{tabular}

${ }^{a}$ Innovation capability is measured with two formative indicators (product innovation capability, process innovation capability) whose correlation is weak $(\mathrm{r}=0.11)$, as should be for such indicators.

\subsection{Test of the Research Hypotheses}

The three research hypotheses are tested by assessing the direction, strength and level of significance of the standardized path coefficients (betas) obtained from the PLS analysis. To test $\mathrm{H}_{2}$ and $\mathrm{H}_{3}$ relative to the moderating effect of IT integration, a hierarchical procedure was followed (Carte and Russell, 2003), wherein a model that excluded the interaction construct (Innovation capability x IT integration) was first estimated. These first results were then compared to the results of estimating the "full" model in which both the main effects and the interaction effects were included, as presented in Table 4.

This research investigates the effect of IT integration on the relationship between SMEs' innovation capabilities, and organizational performance in terms of growth and productivity. The results first indicate that innovation capabilities have a positive and significant effect on growth $(\Omega=$ 0.152, $\mathrm{p}<0.01)$ and on productivity $(\beta=0.219, \mathrm{p}<0.001)$, thus confirming $\mathrm{H} 1_{\mathrm{a}}$, and $\mathrm{H} 1_{\mathrm{b}}$. IT integration has a positive, albeit weakly significant interaction effect with innovation capability in terms of growth $(B=0.066, \mathrm{p}<0.10)$. As a consequence, $\mathrm{H} 2$ is tentatively supported. Whereas an initially surprising result is that IT integration has a significant negative interaction effect with innovation capability in terms of productivity $(B=-0.188, \mathrm{p}<0.01)$, therefore contradicting $\mathrm{H}_{3}$ and disproving the "beneficial" effects most often presumed of IT integration. 
Table 4: Results of Estimating the Research Model with PLS $(n=309)$

\begin{tabular}{|c|c|c|c|c|c|c|}
\hline & \multicolumn{3}{|c|}{ Dependent construct $=$ Growth } & \multicolumn{3}{|c|}{ Dependent construct $=$ Productivity } \\
\hline & Controls & $\begin{array}{l}\text { Main } \\
\text { effects }\end{array}$ & $\begin{array}{c}\text { Main } \\
\text { effects and } \\
\text { interactions }\end{array}$ & Controls & $\begin{array}{l}\text { Main } \\
\text { effects }\end{array}$ & $\begin{array}{c}\text { Main } \\
\text { effects and } \\
\text { interactions }\end{array}$ \\
\hline Innovation capability & & $0.168^{* *}$ & $\begin{array}{c}H_{l a} \\
0.152 * *\end{array}$ & & $0.173^{* *}$ & $\begin{array}{c}H_{l b} \\
0.219^{* * *}\end{array}$ \\
\hline IT integration & & -0.062 & -0.059 & & 0.059 & 0.051 \\
\hline $\begin{array}{c}\text { Innovation capability } \\
\text { x IT integration }\end{array}$ & & & $\begin{array}{c}\mathrm{H}_{2} \\
0.066^{\mathrm{a}} \\
\end{array}$ & & & $\begin{array}{c}H_{3} \\
-0.188 * * \\
\end{array}$ \\
\hline Size of the firm & $0.100^{*}$ & $0.116^{*}$ & $0.114^{*}$ & -0.010 & -0.037 & -0.031 \\
\hline Age of the firm & $-0.198 * * *$ & $-0.185^{* * *}$ & $-0.185^{* * *}$ & $0.103^{*}$ & $0.117 * *$ & $0.117^{* *}$ \\
\hline $\begin{array}{l}\text { Sector } \\
\text { low-tech } \\
\text { medium to high-tech }\end{array}$ & $\begin{array}{l}0.035 \\
0.024 \\
\end{array}$ & $\begin{array}{r}0.063 \\
-0.029 \\
\end{array}$ & $\begin{array}{r}0.061 \\
-0.036 \\
\end{array}$ & $\begin{array}{l}-0.070^{\mathrm{a}} \\
0.203^{* *}\end{array}$ & $\begin{array}{l}-0.043 \\
0.146^{*}\end{array}$ & $\begin{array}{l}-0.036 \\
0.134^{*}\end{array}$ \\
\hline $\mathrm{R}^{2}$ & 0.045 & 0.070 & 0.074 & 0.061 & 0.090 & 0.123 \\
\hline
\end{tabular}

${ }^{\mathrm{a}} \mathrm{p}<0.10 *: \mathrm{p}<0.05 * *: \mathrm{p}<0.01 * * *: \mathrm{p}<0.001$

To further test the significance of the moderating effects of IT integration, these effects were assessed through a pseudo-F test comparing the results of the model estimation with and without the interaction construct (Gopal and Gosain, 2010). As presented in Table 5, these results indicate that the added explained variance obtained by adding the moderating effect of IT integration is not quite significant $(\mathrm{p}>0.10)$ in the case of growth, but is highly significant $(\mathrm{p}<0.001)$ in the case of productivity.

Table 5: Test of the moderation effects $(n=309)$

\begin{tabular}{|c|c|c|c|c|c|}
\hline $\begin{array}{c}\text { IT integration as } \\
\text { moderator }\end{array}$ & $\begin{array}{c}\text { Included } \\
\text { model } \mathrm{R}^{2}\end{array}$ & $\begin{array}{c}\text { Excluded } \\
\text { model } \mathrm{R}^{2}\end{array}$ & $\mathrm{~F}^{2}$ & Pseudo-F $_{(1,303)}$ & Conclusion \\
\hline $\begin{array}{c}\text { Innovation capability } \\
\begin{array}{c}\rightarrow \text { Growth } \\
\text { Innovation capability } \\
\rightarrow \text { Productivity }\end{array}\end{array}$ & 0.074 & 0.070 & 0.004 & 1.21 & not significant \\
\hline
\end{tabular}

Nota. $\mathrm{F}^{2}=\left(\mathrm{R}_{\text {full }}^{2}-\mathrm{R}_{\text {excluded }}^{2} /\left(1-\mathrm{R}_{\text {full }}^{2}\right) \quad\right.$ Pseudo- $\mathrm{F}=\mathrm{F}^{2} *(\mathrm{n}-\mathrm{k}-1)$ with 1 , (n-k) degrees of freedom [where $\mathrm{n}=$ sample size and $\mathrm{k}=$ no. of independent constructs]

Given the preceding results, complementary tests of Hypotheses 2 and 3 were made by computing zero-order and partial correlation coefficients linking Innovation capabilities with Growth 
and Productivity, following a "fit as moderation" approach to strategic IT alignment (Bergeron, Raymond and Rivard, 2001). As prescribed by Venkatraman (1989), the two interaction hypotheses were thus tested by forming two sub-samples based on IT integration, comparing correlations within the "high"- and "low"-integration sub-samples with Z tests, as presented in Table 6. To be regarded as having a high (or low) level of integration, a firm had to have an IT integration score ranking it in the upper (or lower) third of the total sample. The first finding here is that the positive effect of Innovation capabilities on Growth is significantly greater in the high-IT integration SMEs than in the low-IT integration ones. And this remains true when controlling for the sector, the size and the age of the firm, thus providing added support for $\mathrm{H} 2$. The second finding is that the positive effect of Innovation capabilities on Productivity is significantly lesser in firms with a high level of IT integration than in the ones with a low level of IT integration, thus providing further contradictory evidence for $\mathrm{H} 3$.

Table 6: Correlation of Innovation capability with Growth and Productivity in SMEs with low and high levels of IT integration

\begin{tabular}{|c|c|c|c|c|c|c|}
\hline \multirow[b]{3}{*}{ correlation } & \multicolumn{4}{|c|}{ IT integration } & \multirow{3}{*}{$\mathrm{Z}^{\mathrm{b}}$} & \multirow{3}{*}{$\mathrm{Z}$} \\
\hline & \multicolumn{2}{|c|}{$\begin{array}{c}\text { Low } \\
(\mathrm{n}=105)\end{array}$} & \multicolumn{2}{|c|}{$\begin{array}{c}\text { High } \\
(\mathrm{n}=99)\end{array}$} & & \\
\hline & zero-order & partial $^{\mathrm{a}}$ & zero-order & partial & & \\
\hline $\begin{array}{l}\text { Innovation capability } \\
\quad \rightarrow \text { Growth }\end{array}$ & 0.049 & 0.046 & $0.280 * *$ & $0.271 * *$ & $-1.68 *$ & $-1.58^{\mathrm{c}}$ \\
\hline $\begin{array}{c}\text { Innovation capability } \\
\rightarrow \text { Productivity }\end{array}$ & $0.456 * * *$ & $0.366 * * *$ & 0.070 & 0.052 & $2.97 * *$ & $2.26^{*}$ \\
\hline
\end{tabular}

${ }^{\mathrm{a}}$ controlling for Sector, Size and Age of the firm

$b_{\text {test }}$ of the significance of the difference between two correlation coefficients

${ }^{\mathrm{c}} \mathrm{p}<0.10 *$ : $\mathrm{p}<0.05 \quad * *: \mathrm{p}<0.01 \quad * * *: \mathrm{p}<0.001$

Although innovation capability leads to growth and productivity, the level of IT integration in the firms plays a different role dependent upon the performance objectives (growth vs. productivity). In terms of growth, IT integration exerts a positive effect, in that organizations that develop their innovation capability by conducting $R \& D$ in a more integrated IT environment show a relatively higher rate of growth than organizations that develop their innovation capability in a less integrated IT environment. IT integration's moderating effect on the SME's innovation capability is therefore 
relatively beneficial to its growth performance.

With regard to productivity and contrary to what was expected, the results indicate that IT integration's moderating effect on the firm's innovation capability is detrimental rather than beneficial to its productivity. Manufacturing SMEs that develop their innovation capability in a more integrated IT environment have a lower productivity than organizations that develop this innovation capability in a less integrated IT environment. An explanation of this last result may be found in Markus' (2000) assertion that the more an organization is integrated through IT, the harder it is to "disconnect" itself, and in Elbanna's (2006) qualification of ERP and other integrative IT as "rigid" rather than "malleable" technology. This is also in line with previous empirical findings to the effect that the more firms adopt integrated technologies, the less flexible they are (Brandyberry, Rai and White, 1999).

\section{Discussion}

One can make several interpretations of the results obtained in this study. Overall, IT integration enables innovation capabilities with regard to growth but disables these with regard to productivity. This might be due to the fact that a highly IT-integrated firm hampers the possibility to increase productivity where the proposed changes in new product development and manufacturing processes might conflict with existing processes. The human and technical problems as well as the time needed to introduce the new processes directly affect productivity in terms of gross profit per employee. The more existing processes are inter-connected, the less it is possible to change them without decreasing productivity, at least in the short term. However, this conflict does not show up in the relationship with growth. It might be that highly inter-connected processes allow the firm to rapidly introduce new products on the market. This is observed overall and specifically for medium to high-tech SMEs. Now, IT integration includes both internal and external integration. Thus, the time needed to launch a new product resulting from $R \& D$ efforts can be shortened significantly if the internal new product development and manufacturing processes are highly integrated with the external processes, i.e. the backbone of the extended value chain. In this case, organizational growth, 
measured in terms of increased sales, shows a positive improvement.

The target period of the measurements may allow for additional explanation. While IT integration seems a legitimate goal, it might not be profitable at least in the short run. In the long run, adjustments can likely be made where new manufacturing processes are implemented and streamlined for a greater organizational productivity. The nature of the sample might also come into play. In this research, firms of an entrepreneurial or aggressive strategic type are seemingly more represented than they would be in a random sample. These organizations need to innovate to "stay ahead of the crowd", and IT integration may not be their main priority since they may instead favor flexibility.

Also, IT integration might be counterproductive in a context where the manufacturing SME must renew its productive apparatus in order to become more agile in view of increasingly complex demands from customers. Such renewal however would be made more difficult by the process "discipline" imposed by IT integration, for instance by the "best practices" embedded in an ERP system. In other contexts, such as in a production environment where the SMEs are more of the managerial or defensive type, it might be that greater IT integration is a must. Thus, the type of business strategy might be a contingency factor to consider when designing a plan to inter-connect business processes through IT.

Having lent further empirical credence to the "moderator" role played by information technology with regard to innovation capability, these results have several implications for IS researchers. In line with Fichman (2004) who suggests that researchers go "beyond the dominant paradigm for information technology innovation research", we propose that the counterproductive effect of IT integration with regard to the innovation capability of SMEs and large firms be more closely studied. As this study is cross-sectional, we are left with a number of questions about whether, when, and how developing a product and process innovation capability while increasing IT integration can be beneficial and profitable to organizations (Swanson and Ramiller, 2004). At first glance, the negative effect of a process innovation capability on business productivity in a highly integrated IT environment is counter-intuitive and somewhat paradoxical. On one hand, it is well known that strategic capabilities such as the capacity to innovate are required to achieve competitiveness in a global market. On the other hand, IT integration software such as ERP is 
strongly advocated to streamline activities and enhance the firm's performance. In this case, organizations that combine both end up with lower productivity.

As suggested by Fichman (2004), several perspectives could be adopted by IS researchers to study innovation capability. While contagion effects, management fashion and innovation mindfulness have already come to the attention of innovation researchers, other areas such as innovation configurations, technology destiny, quality of innovation, and technology savvy (Weill and Aral, 2006; Weill and Ross, 2009) and performance impacts are yet to be analyzed. And as IT "may matter" in different ways, depending upon the firm's innovation strategy, be it outward-bound and growth-oriented (as for Miles and Snow's "prospector" strategic type), or inward-bound and productivity-oriented (as for the "defender" type), IS researchers should also examine the effects of this strategy on IT integration. These perspectives, as they relate to organizational performance, seem promising avenues to develop a more comprehensive and sounder understanding of the "IT integration paradox", illustrated here by the lower productivity of highly IT-integrated firms that show a strong process innovation capability.

This study has also generated implications for small business owner-managers and consultants, given results showing that investing in IT is not automatically beneficial to manufacturing SMEs but may in fact be counterproductive in certain situations or contexts, and particularly in medium to high-tech industries. As their greater flexibility is deemed to be the main competitive advantage of SMEs in local, national and now in international markets, care must be taken to preserve this flexibility when implementing IT-based solutions such as ERP and EDI that are principally meant by their purveyors to inter-connect intra- and inter-organizational business processes. Here, the IT adoption principle of choice is that the system should be adapted to the organization rather than the opposite. Thus, "seamless" integration solutions implemented as such, say "vanilla" implementations of enterprise systems, may induce too much rigidity in supply-chain, production and distribution processes and generate conversion costs that inhibit the SME's process R\&D efforts aimed at increasing its productivity.

A mindfully-designed and implemented IT infrastructure should be adaptable to changing 
business, systems, technology, and data architectures and be aligned with the manufacturing SME's business and innovation strategy, be it oriented toward growth or productivity, in order to enhance the positive effects of innovation capability on growth, curb potentially negative effects on productivity and shorten the adaptation period to the new process environment. Thus, in the case of the packaged integrated solutions that are proposed to SMEs by vendors and other third parties such as integrators and consultants, the "one size fits all" approach is clearly inadequate. Vendors and others should thus attempt to tailor their offer to the industrial context of the SMEs targeted, be it low, medium or hightech, and render their products and services sufficiently adaptable, to prevent misalignment between their solution's integrative functionalities and the adopting organization's need to preserve its flexibility and innovativeness.

In practice, given that innovation is so crucial to the SME's survival, growth and productivity, IT vendors should always include an analysis of the impact of IT integration on the firm's innovation capability. Vendors could begin their consulting work by characterizing the firm's strategic objectives in terms of growth and productivity. The following step would be to characterize the SME's technological intensity relative to the industry in which it operates. Various IT integration scenarios could then be examined in order to propose a solution that meets IT integration goals while preserving the firm's innovation capability, given its specific industrial and technological context. The retained IT integration solution should thus be the one that is most beneficial in operational and economic terms while being the less disruptive of the SME as a whole.

\section{Limitations and Conclusion}

This study has certain limitations that must be mentioned. Given that the sample is composed of selfselected firms, there could thus be a sample bias in that these firms may differ from the general population in regard to their innovation capability, IT integration, and performance (Cassell, Nadin and Gray, 2001). Other than the nature of the sample that prevents the generalisation of the findings to enterprises of all sizes, another limit associated to survey research pertains to the use of a perceptual measure of IT integration that demands prudence in generalising results. The measure of innovation 
capability based on R\&D budget, while commonly used in empirical research, may not adequately reflect the breadth and depth of the SMEs' capabilities in matters of product and process innovation. The cross-sectional rather than longitudinal nature of the study moreover implies that the results do not necessarily reflect the long-term enabling effects of IT on innovation capability. There may also be a time lag between the investment in $\mathrm{R} \& \mathrm{D}$, as a measure of innovation capability, and its realized impacts.

One can conclude from the results of this study that IT "does matter" for innovation capability in manufacturing SMEs. While IT integration is seen to enable the product innovation of manufacturing SMEs by increasing their growth, it tends to disable their process innovation capability by decreasing the productivity of these organizations. This is the paradox of IT integration in manufacturing and why there is a need for future research on the innovation-IT integration relationship. And as the effect of IT integration been shown here to vary across industries, such research should definitely take industry effects into account. Indeed, studying the IT integration paradox through the effect of a product or a process lifecycle would help in ascertaining the optimal level of IT integration (Lee and Stone, 1994). The same approach could also be applied to the SME's level of organizational maturity, in a fashion similar to Raymond and Croteau (2006) who observed mature firms to outperform emerging ones in terms of productivity and growth through their use of advanced manufacturing systems. It would then be interesting to ascertain whether a mature firm achieves greater advantage from IT integration than an emerging firm.

In confronting the dominant paradigm in innovation research, evidence has been provided that integrative IT such as ERP systems can indeed be counterproductive, and "seamless integration" can induce rigidities that run counter to process innovation aims. Further understanding of the potential dialogic between IT integration and IT flexibility is needed if these technologies are to effectively enable the operational and managerial processes of SMEs, thus improving the organizational performance of these firms and helping them achieve "world-class" manufacturing status. 


\section{References}

Acs, Z.J. and Audretsch, D.B. (1990), Innovation and Small Firms, MIT Press, Cambridge, Massachusetts.

Aragón-Sánchez, A. and Sánchez-Marín, G. (2005), Strategic orientation, management characteristics, and performance: A study of Spanish SMEs, Journal of Small Business Management, Vol. 43, No. 3, pp. 287-308.

Aral, S., Brynjolfsson, E. and Wu, D.J. (2009), Which came first, IT or productivity? Virtuous cycle of investment and use in enterprise systems, Working Paper available at SSRN: http://ssrn.com/abstract=942291, accessed May 22, 2009.

Ariss, S.S., Raghunathan, T.S. and Kunnathar, A. (2000), Factors affecting the adoption of advanced manufacturing technology in small firms, SAM Advanced Management Journal, Vol. 56, No. 2, pp. 14-21

Bagchi, P.K. and Skjoett-Larsen, T. (2002), Integration of information technology and organizations in a supply chain, The International Journal of Logistics Management, Vol. 14, No. 1, pp. 89-108.

Bailey, M.N., Bartelsman, E.J. and Haltiwanger, J. (1996), Downsizing and productivity growth: Myth or reality?, Small Business Economics, Vol. 8, pp. 259-278.

Baldwin, J.R. and Hanel, P. (2003), Innovation and Knowledge Creation in an Open Economy: Canadian Industry and International Implications, Cambridge University Press, Cambridge, United Kingdom.

Banker, R., Bardhan, I., Chang, H. and Lin, S. (2003), Impact of manufacturing practices on adoption of plant information systems, Proceedings of the Twenty-Fourth International Conference on Information Systems, pp. 233-245.

Barclay, D., Higgins, C. and Thompson, R. (1995), The partial least squares (PLS) approach to causal modeling: Personal computer adoption and use as an illustration, Technology Studies, Vol. 2, No. 2, pp. 285-309.

Barki, H. and Pinsonneault, A. (2005), A model of organizational integration, implementation effort, and performance, Organization Science, Vol.16, No. 2, pp. 165-179.

Barry, F. (2005), FDI, transfer pricing and the measurement of R\&D intensity, Research Policy, Vol. 34, pp. 673-681.

Barua, A., Konana, P., Whinston, A.B. and Yin, F. (2004), An empirical investigation of net-enabled business value, MIS Quarterly, Vol. 28, No. 4, pp. 585-620.

Becheikh, N., Landry, R. and Amara, N. (2006), Lessons from innovation empirical studies in the manufacturing sector: A systematic review of the literature from 1993-2003, Technovation, Vol. 26, No. 5/6, pp. 644-664.

Benner, M.J. and Tushman, M. (2002), Process management and technological innovation: A longitudinal study of the photography and paint industries, Administrative Science Quarterly, Vol. 47, No. 4, pp. 676-706.

Benner, M.J. and Tushman, M.L. (2002), Exploitation, exploration, and process management: The productivity dilemma revisited, Academy of Management Review, Vol. 28, No. 2, pp. 238-256.

Bergeron, F., Raymond, L. and Rivard, S. (2001), Fit in strategic information technology management research: An empirical comparison of perspectives, Omega, Vol. 29, No. 2, pp. 125-142.

Bharadwaj, A. (2000), A resource-based perspective on the information technology capability and firm performance: An empirical investigation, MIS Quarterly, Vol. 24, No. 1, pp. 169-196.

Bharadwaj, A.S., Bharadwaj, S.G. and Konsynski, B.R. (1995), The moderator role of information technology in firm performance: A conceptual model and research propositions, Proceedings of the Sixteenth International Conference on Information Systems, Amsterdam, pp. 183-188

Bhattacharya, M. and Bloch, H. (2004), Determinants of innovation, Small Business Economics, Vol. 22, No. 2, pp. 155-162.

Bottazi, G., Secchi, A. and Tamagni, F. (2008), Productivity, profitability and financial fragility, Industrial and Corporate Change, Vol. 17, No. 4, pp. 711-751.

Brandyberry, A., Rai, A. and White, G.P. (1999), Intermediate performance impacts of advanced manufacturing technology systems: an empirical investigation, Decision Sciences, Vol. 30, No. 4, pp. 993-1020. 
Branzei, O. and Vertinsky, I. (2006), Strategic pathways to product innovation capabilities in SMEs, Journal of Business Venturing, Vol. 21, pp. 75-105.

Carte, T.A. and Russell, C.J. (2003), In pursuit of moderation: Nine common errors and their solution, MIS Quarterly, Vol. 27, No 3, pp. 479-501.

Cassell, C., S. Nadin and Gray, M.O. (2001), The use and effectiveness of benchmarking in SMEs, Benchmarking: An International Journal, Vol. 8, No. 3, pp. 212-222.

Chatterjee, D., Grewal, R. and Sambamurthy, V. (2002), Shaping up for e-commerce: Institutional enablers of the organizational assimilation of web technologies, MIS Quarterly, Vol. 26, No. 2, pp. 65-89.

Chiasson, M. and Davidson, E. (2005), Taking industry seriously in information systems research, MIS Quarterly Vol. 29, No. 4, pp. 591-605.

Chin, W.W., Marcolin, B.L. and Newsted, P.R. (2003), A partial least squares latent variable modeling approach for measuring interaction effects: Results from a Monte Carlo simulation study and an electronic-mail emotion/adoption study, Information Systems Research, Vol. 14, No. 2, pp. 189-217.

Cooper, R.B. and Zmud, R.W. (1990), Information technology implementation research: A technological diffusion approach, Management Science, Vol. 36, No. 2, pp. 123-139.

D'Adderio, L. (2003), Configuring software, reconfiguring memories: the influence of integrated systems on the reproduction of knowledge and routines, Industrial and Corporate Change, Vol. 12, No. 2, pp. 321-350.

de Búrca, S., Fynes, B. and Brannick, T. (2006), The moderating effects of information technology sophistication on services practice and performance, International Journal of Operations \& Production Management, Vol. 26, No. 11, pp. 1240-1254.

Delery, J.E. and Doty, D.H. (1996), Modes of theorizing in strategic human resource management: Tests of universalistic, contingency and configurational performance predictions, Academy of Management Journal, Vol. 39, No. 4, pp. 802-835.

Delmar, F., Davidsson, P. and Gartner, W.B. (2003), Arriving at the high-growth firm, Journal of Business Venturing, Vol.18, pp. 189-216.

DeSarbo, W.S., Di Benedetto, C.A., Song, M. and Sinha, I. (2005), Revisiting the Miles and Snow strategic framework: Uncovering interrelationships between strategic types, capabilities, environmental uncertainty, and firm performance, Strategic Management Journal, Vol. 26, pp. 47-74.

Dechow, N. and Mouritsen, J. (2005), Enterprise resource planning systems, management control and the quest for integration, Accounting, Organizations and Society, Vol. 30, No. 7/8, pp. 691-733.

Dibrell, C., Davis, P.S. and Craig, J. (2008), Fueling innovation through information technology in SMEs, Journal of Small Business Management, Vol. 46, No. 2, pp. 203-218.

Dugal, S.S. and Roy, M.H. (1996), The allocation of R\&D funds between product development and process improvements: a follow-up study, Journal of Strategic Marketing, Vol. 4, No. 2, pp. 117 127.

Elbanna, A.M. (2006), The validity of the improvisation argument in the implementation of rigid technology: the case of ERP systems, Journal of Information Technology, Vol. 21, pp. 165-175.

Evgeniou, T. (2002), Information integration and information strategies for adaptive enterprises, European Management Journal, Vol. 20, No. 5, pp. 486-494.

Fergurson, P.R. and Fergurson, G.J. (1994), Industrial Economics: Issues and Perspectives, $2^{\text {nd }}$ edition, Palgrave, Hampshire.

Fichman, R.G. (2004), Going beyond the dominant paradigm for information technology innovation research: Emerging concepts and methods, Journal of the Association for Information Systems, Vol. 5, No. 8, pp. 314-355.

Fichman, R.G. and Kemerer, C.F. (1997), The assimilation of software process innovations: An organizational learning perspective, Management Science, Vol. 43, No. 10, pp. 1345-1363.

Fornell, C.R. and Larcker, D.F. (1981), Two structural equation models with unobservable variables and measurement error", Journal of Marketing Research, Vol. 18, pp. 39-50.

Foster, L., Haltiwanger, J. and Krizan, C.J. (2001), New Developments in Productivity Analysis, 
University of Chicago Press, Chicago.

Freel, M.S. (2000), Strategy and structure in innovative manufacturing SMEs: the case of an English region, Small Business Economics, Vol. 15, pp. 27-45.

Furber, P., Enterprise Architecture - Goal or Journey, http://www.sas.com/offices, accessed May 22, 2009.

Gable, G. and Stewart, G. (1999), SAP R/3 implementation issues for small to medium enterprises, Proceedings of the $5^{\text {th }}$ Americas Conference on Information Systems, Milwaukee, Wisconsin, pp. 779-781.

Gefen, D.D., Straub, D.W. and Boudreau, M.-C. (2000), Structural equation modeling and regression: Guidelines for research practice, Communications of the Association for Information Systems, Vol. 4, No. 7, pp. 2-77.

Goodhue, D., Wybo, M. and Kirsch, L. (1992), The impact of data integration on the costs and benefits of information systems, MIS Quarterly, September, pp. 293-310.

Gopal, A. and Gosain, S. (2010), The role of organizational controls and boundary spanning in software development outsourcing: Implications for project performance, Information Systems Research, Vol. 21, No 4, pp. 960-982.

Hall, B.H., Lotti, F. and Mairesse, J. (2009), Innovation and productivity in SMEs: empirical evidence for Italy, Small Business Economics, Vol. 33, pp. 13-33.

Henseler,J. and Fassot, G. (2010), Testing moderating effects in PLS path models: an illustration of available procedures, in Handbook of Partial Least Squares: Concepts, Methods and Applications, Esposito Vinzi, V., Chin, W.W., Henseler, J. and Wang, H. (Eds), Springer, Heidelberg, pp. 713-735.

Heygate, R. (1996), Why are we bungling process innovation? The McKinsey Quarterly, Vol. 2, pp. 130-141.

Hoffman, K., Parejo, M. Bessant, J. and Perren, L. (1998), Small firms, R\&D, technology and innovation in the UK: a literature review, Technovation, Vol. 18, No. 1, pp. 39-55.

Hwang, Y. and Grant, D. (2011), Understanding the influence of integration on ERP performance, Information Technology and Management, Vol. 12, No. 3, pp. 229-240.

Izza, S., (2009), Integration of industrial information systems: from syntactic to semantic integration approaches, Enterprise Information Systems, Vol. 3, No. 2, pp. 1- 57.

Kalantaridis, C. and Pheby, J. (1999), Processes of innovation among manufacturing SMEs: the experience of Bedfordshire, Entrepreneurship \& Regional Development, Vol. 11, pp. 57-78.

Khalifa, M. and Liu, V. (2003), Determinants of successful knowledge management programs, Electronic Journal on Knowledge Management, Vol. 1, No. 2, pp. 103-112.

Kobayashi, T., Tamaki, M. and Komoda, N. (2003), Business process integration as a solution to the implementation of supply chain management systems, Information \& Management, Vol. 40, pp. 769-780.

Kohli, R. and Grover, V. (2008), Business value of IT: An essay on expanding research directions to keep up with the times, Journal of the Association for Information Systems, Vol. 9, No. 1, pp. 23 39.

Kotha, S. and Swamidass, P.M. (2000), Strategy, advanced manufacturing technology and performance: empirical evidence from U.S. manufacturing firms, Journal of Operations Management, Vol. 18, No. 3, pp. 257-277.

Lee, H., Farhoomand, A. and Ho, P. (2004), Innovation through supply chain recognition, MIS Quarterly Executive, Vol. 3, No. 3, pp. 131-142.

Lee, H.-H. and Stone, J. A. (1994), Product and process innovation in the product life cycle: Estimates for U. S. manufacturing industries, Southern Economic Journal, Vol. 60, No. 3, pp. 754-763.

Lefebvre, L.-A., Lefebvre, E. and Colin, D. (1991), Process innovation, productivity, and competitiveness in smaller manufacturing firms, Canadian Journal of Administrative Sciences, Vol. 8, No. 1, pp. 19-28.

Lim, L.P.L., Garnsey, E. and Gregory, M. (2006), Product and process innovation in biopharmaceuticals: a new perspective on development, $R \& D$ Management, Vol. 36, No. 1, pp. 27-36.

Lin, S.-P., Lo, S.-H., and Yang, H.-L. (2010), Information system integration after merger and 
acquisition in the banking industry, World Academy of Science, Engineering and Technology, Vol. 72, pp. 189-193.

Luftman, J. and Ben-Zvi, T. (2011), Key Issues for IT Executives 2011: Cautious optimism in uncertain economic times, MIS Quarterly Executive, Vol. 10, No. 4, pp. 203-212.

Mankin, E. (2006), IT \& innovation: Out of sync?, Optimize, Issue 22, October, pp. 1-4 (http://www.wirelessnetdesignline.com/showArticle.jhtml?articleID=193006221).

Marelli, E. and Signorelli, M. (2010), Employment, productivity and models of growth in the EU, International Journal of Manpower, Vol. 31, No. 7, pp. 732-754.

Markus, M.L. (2000), Paradigm shifts: e-business and business systems integration, Communications of the Association for Information Systems, Vol. 4, article 10, pp. 1-44.

Markus, M.L. (2001), Reflections on the systems integration enterprise, Business Process Management Journal, Vol. 7, No. 3, 2001, pp. 171-180.

Mauri, A.J. and Michaels, M.P. (1998), Firm and industry effects within strategic management: An empirical examination, Strategic Management Journal, Vol. 19, No. 3, pp. 211-219.

Miles R. E. and Snow C.C. (1978), Organizational Strategy, Structure, and Process, McGraw-Hill, New York.

Mittelstaedt, J.D., Harben, G.N. and Ward, W.A. (2003), How small is too small? Firm size as a barrier to exporting from the United States, Journal of Small Business Management, Vol. 41, No.1, pp. 68-84.

Moreno, A.M. and Casillas, J.C. (2007), High-growth SMEs versus non-high-growth SMEs: A discriminate analysis, Entrepreneurship \& Regional Development, Vol. 19, No. 1, pp. 69-88.

Nummela, N., Puumalainen, K. and Saarenketo, S. (2005), International growth orientation of knowledge-intensive SMEs, Journal of International Entrepreneurship, Vol. 3, pp. 5-18.

Muscatello, J.R., Small, M.H. and Chen, I.J. (2003), Implementing enterprise resource planning (ERP) systems in small and midsize manufacturing firms, International Journal of Operations \& Production Management, Vol. 23, No. 8, pp. 850-871.

Nyström, K. (2005), Firm maturity and product and process R\&D in Swedish manufacturing firms, Working Paper Series in Economics and Institutions of Innovation, Paper No. 39, Centre of Excellence for Science and Innovation Studies, Royal Institute of Technology, Stockholm.

OECD (2005a), Oslo Manual: Guidelines for Collecting and Interpreting Innovation Data, $3^{\text {rd }}$ edition, OECD, Paris.

O'Regan, N. and Ghobadian, A. (2005), Innovation in SMEs: the impact of strategic orientation and environmental perceptions, International Journal of Productivity and Performance Management, Vol. 54, No. 2, pp. 81-97.

Overby, E, Bharadwaj, A. and Sambamurthy, V. (2006), Enterprise agility and the enabling role of information technology, European Journal of Information Systems, Vol. 15, pp. 120-131.

Oz, E. (2005), Information technology productivity: in search of a definite observation, Information \& Management, Vol. 42, pp. 789-798

Özsomer, A., Calantone, R.J. and Di Benedetto, A. (1997), What makes firms more innovative? A look at organizational and environmental factors, Journal of Business \& Industrial Marketing, Vol. 12, No. 6, pp. 400-416.

Park, K. and Kusiak, A. (2005), Enterprise resource planning (ERP) operations support system for maintaining process integration, International Journal of Production Research, Vol. 43, No. 19, pp. 3959-3982.

Pflughoeft, K.A., Ramamurthy, K., Soofi, E.S., Yasai-Ardekani, M. and Zahedi, F. (2003), Multiple conceptualizations of small business Web use and benefit, Decision Sciences, Vol. 34, No. 3, pp. 467-512.

Premkumar, G. (2003), A meta-analysis of research on information technology implementation in small business, Journal of Organizational Computing and Electronic Commerce, Vol. 13, No. 2, pp. 91-121.

Qian, G. and Li, L. (2003), Profitability of small and medium-sized enterprises in high-tech industries: The case of the biotechnology industry, Strategic Management Journal, Vol. 24, No. 9, pp. 881887.

Rai, A., Tang, X., Brown, P. and Keil, M. (2006), Assimilation patterns in the use of electronic procurement innovations: A cluster analysis, Information \& Management, Vol. 43, pp. 336-349. 
Rai, A., Patnayakuni, R. and Seth, N. (2006), Firm performance impacts of digitally enabled supply chain integration capabilities, MIS Quarterly, Vol. 30, No. 2, pp. 225-246.

Raymond, L. and Croteau, A.-M. (2006), Enabling the strategic development of SMEs through advanced manufacturing systems: A configurational perspective, Industrial Management \& Data Systems, Vol. 106, No. 7, pp. 1012-1032.

Raymond, L. and Croteau, A.-M. (2009), Manufacturing strategy and business strategy in mediumsized enterprises: Performance effects of strategic alignment, IEEE Transactions on Engineering Management, Vol. 56, No. 2, pp. 192-202.

Rochina-Barrachina, M.E., Mañez, J.A. and Sachis-Llopis, J.A. (2010), Process innovations and firm productivity growth, Small Business Economics, Vol. 34, pp. 147-166.

Roper, S. and Love, J.H. (2002), Product innovation and small business growth: A comparison of the strategies of German, U.K. and Irish companies", Research Policy, Vol. 31, pp. 1087-1102.

Ross, J.W. (2003), Creating a strategic IT architecture competency: learning in stages, MIS Quarterly Executive, Vol. 2, No. 1, pp. 31-43.

Sambamurthy, V., Bharadwaj, A. and Grover, V. (2003), Shaping agility through digital options: Reconceptualizing the role of information technology in contemporary firms, MIS Quarterly, Vol. 27, No. 2, pp. 237-263.

Santamaria, L., Nieto, M.J. and Miles, I. (2011), Service innovation in manufacturing firms: Evidence from Spain, Technovation, Vol. 32, pp. 144-155.

Singletary, L.A. (2004), Applications integration: Is it always desirable?, Proceedings of the $37^{\text {th }}$ Hawaii International Conference on System Sciences, pp. 1-9.

Slater, S.F. and Narver, J.C. (1993), Product-market strategy and performance: an analysis of the Miles and Snow strategy types, European Journal of Marketing, Vol. 27, No. 10, pp. 33-51.

Srivardhana, T. and Pawlowski, S.D. (2009), ERP systems as an enabler of sustained business process innovation: A knowledge-based view, Journal of Strategic Information Systems, Vol. 16, pp. 51 69.

Stoel, M.D. and Muhanna, W. A. (2009), IT capabilities and firm performance: A contingency analysis of the role of industry and IT capability type, Information \& Management, Vol. 46, pp. 181-189.

Stratopoulos, T. and Dehning, B. (2000), Does successful investment in information technology solve the productivity paradox? Information \& Management, Vol. 30, pp. 103-117.

Subrahmanya, M.H.B. (2005), Pattern of technological innovations in small enterprises: a comparative perspective of Bangalore (India) and Northeast England (UK), Technovation, Vol. 25, pp. 269-280.

Sum, C., Kow, L.S.-J. and Chen, C.-S. (2004), A taxonomy of operations strategies of high performing small and medium enterprises in Singapore, International Journal of Operations \& Production Management, Vol. 24, No. 3, pp. 321-345.

Swafford, P.M., Ghosh, S. and Murthy, N. (2008), Achieving supply chain agility through IT integration and flexibility, International Journal of Production Economics, Vol. 116, pp. 288-297.

Swanson, E.B. and Ramiller, N.C. (2004), Innovating mindfully with information technology, MIS Quarterly, Vol. 28, No. 4, pp. 553-583.

Swink, M. and Nair, A. (2007), Capturing the competitive advantage of AMT: Design-Manufacturing integration as a complementary asset, Journal of Operations Management, Vol. 25, No. 3, pp. 736-754.

Tarafdar, M. and Gordon, S.R. (2007), Understanding the influence of innovation systems competencies on process innovation: A resource-based view, Journal of Strategic Information Systems, Vol. 16, pp. 353-392.

Thong, J.Y.L., Yap, C.-S. and Raman, K.S. (1996), Top management support, external expertise and information systems implementation in small businesses, Information Systems Research, Vol. 7, No. 2, pp. 248-267.

Tidd, J. (2001), Innovation management in context: environment, organization and performance, International Journal of Management Reviews, Vol. 3, No. 3, pp. 169-183.

Tidd, J., Bessant, J. and Pavitt, K. (2005), Managing Innovation: Integrating Technological, Market and Organizational Change, $3^{\text {rd }}$ Edition, John Wiley, Chichester, U.K.

Tornatzky, L.G. and Klein, K. (1982), Innovation characteristics and innovation implementation: A 
meta-analysis of findings, IEEE Transactions on Engineering Management, Vol. 29, No. 1, pp. $28-45$.

Uwizeyemungu, S. and Raymond, L. (2012), Impact of an ERP system's capabilities upon the realisation of its business value: A resource-based perspective, Information Technology and Management, Vol. 13, No. 2, pp. 69-90.

Van Grembergen, W. and Van Belle, J.-L. (1999), Process integration through information technology at the Générale de Banque of Belgium, Journal of Strategic Information Systems, Vol. 8, pp. 6381.

Venkatraman, N. (1989), The concept of fit in strategy research: toward verbal and statistical correspondence, Academy of Management Review, Vol. 14, No. 3, pp. 423-444.

Vernadat, F.B. (2002), Enterprise modelling and integration (EMI): Current status and research perspectives, Annual Reviews in Control, Vol. 26, pp. 15-25.

Wang, E.T.G., Ju, P-H, Jiang, J.J. and Klein, G. (2008), The effects of change control and management review on software flexibility and project performance, Information \& Management, Vol. 45, pp. 438-443

Ward, P. and Zhou, H. (2006), Impact of information technology integration and lean/just-in-time practices on lead-time performance, Decision Sciences, Vol. 37, No. 2, pp. 177-203.

Weill, P. and Aral, S. (2006), Generating premium returns on your IT investments, Sloan Management Review, Vol. 47, No. 2, pp. 38-48.

Weill, P. and Ross, J.W. (2009), IT Savvy, Harvard Business Press, Watertown, Massachusetts.

Wiklund, J. and Sheperd, D. (2003), Aspiring for, and achieving growth: the moderating role of resources and opportunities, Journal of Management Studies, Vol. 40, No. 8, pp. 19111941.

Wolff, J.A. and Pett, T.L. (2006), Small-firm performance: modeling the role of product and process improvements, Journal of Small Business Management, Vol. 44, No. 2, pp. 268-284.

Wright, R.E., Palmer, J.C. and Perkins, D. (2005), Types of product innovations and small business performance in hostile and benign environments, Journal of Small Business Strategy, Vol. 15, No. 2, pp. 33-44.

Zhu, K. and Kraemer, K.L. (2005), Post-adoption variations in usage and value of e-business by organizations: Cross-country evidence from the retail industry, Information Systems Research, Vol. 16, No. 1, pp. 61-84.

Zhu, K., Kraemer, K.L. and Xu, S. (2006), The process of innovation assimilation by firms in different countries: A technology diffusion perspective on e-business, Management Science, Vol. 52, No. 10, pp. 1557-1576. 